\title{
THE INFLUENCE OF DEPENDENCES OF PSYCHOPHYSIOLOGICAL CHARACTERISTICS OF DRIVERS
}

\author{
Galina Rozum, ORCID: 0000-0002-8962-88861, \\ Julia Pashkovskaia, ORCID: 0000-0002-5730-88531, \\ Katerina Ivanova, ORCID: 0000-0001-8103-43651, \\ Viktor Sontea, ORCID: 0000-0002-0372-8799² \\ ${ }^{1} \mathrm{U}$ Belarusian State University of Informatics and Radioelectronics, Department of Engineering Psychology and \\ Ergonomics, st. P. Brovki, 6, Minsk, 220013, Republic of Belarus \\ ${ }^{2}$ Technical University of Moldova, 168 Stefan cel Mare blvd., Chisinau, Republic of Moldova \\ *Corresponding author: Galina Rozum, rozum@bsuir.by \\ Received: 10. 03. 2021 \\ Accepted: 11. 17. 2021
}

\begin{abstract}
The article analyzes the "man-machine-environment" system in relation to the psychophysiological characteristics of the driver - "human operator". The methods of diagnosing the psychophysiological characteristics of drivers were analyzed. The dependencies between the parameters of psychophysiological characteristics were established: complex visual-motor reaction and emotional stability (Pearson correlation coefficient $r=-0.7$ ), as well as the correlation between emotional stability and the level of perception of speed and distance $(r=0.5)$. The psychophysiological characteristics at different stages of the driving experience were revealed and practical recommendations were formulated for their development.
\end{abstract}

Keywords: psychophysiological characteristics, professional important qualities, hardware and software diagnostic complex, monitoring, vehicle drivers.

Rezumat. Articolul analizează sistemul „om-mașină-mediu” în raport cu caracteristicile psihofiziologice ale șoferului - „operator uman”. Sunt analizate metodele de diagnosticare a caracteristicilor psihofiziologice ale conducătorilor auto. Au fost stabilite dependențele dintre parametrii caracteristicilor psihofiziologice: reacție vizual-motorie complexă și stabilitate emoțională (coeficientul de corelație Pearson $r=-0,7$ ), precum și corelația dintre stabilitatea emoțională și nivelul de percepție a vitezei și distanței $(r=0,5))$. Au fost dezvăluite caracteristicile psihofiziologice în diferite etape ale experienței de conducere și au fost formulate recomandări practice pentru dezvoltarea acestora.

Cuvinte cheie: caracteristici psihofiziologice, calități profesionale importante, complex de diagnosticare hardware și software, monitorizare, șoferi de vehicule. 


\section{Introduction}

One of the priority areas of the state activity is ensuring road safety and creating an effective system for the prevention of road accidents. Driving a vehicle is complicated by the high traffic intensity and the presence of vehicle drivers with different levels of training in modern conditions.

These circumstances cause a significant increase in neuropsychic stress, which occurs in difficult, stressful conditions and require the body to adapt [1, 2]. They significantly increase the likelihood of developing negative changes in the psychophysiological functional state of a person, manifested in a decrease in the level of mental or psychophysiological adaptation and entail errors, as a result of which the number of road accidents increases.

According to statistics, about $70 \%$ of road traffic accidents are the reasons of driver errors. Road accidents are the leading cause of death of people aged 15 to 29. The roads of European countries considered to be the safest, where the index does not exceed 10 people per 100 thousand population. The lowest rates are in the UK and Sweden (2.9 and 2.8 deaths per 100 thousand population) [3]. Also, car driver is the most risk profession of fatal injury index [4].

The article reveals the system "human-machine-environment" in relation to the psychophysiological characteristics of the driver, or "human operator", then "machiner" - a vehicle (car) and, accordingly, "environment" - external road, weather conditions.

Road safety is determined by the reliability of the whole system and the reliability of each of its components [5]. Failure of at least one element of the system can lead to a traffic accident.

We should note that one of the most important ensuring traffic safety skills of a driver is his speed of reaction - the natural response of the body to external influences [6].

The term "reaction time" may be defined simply as the time between a stimulus and a response. Any response of the body to a change in the external or internal environment: from the biochemical reaction of an individual cell to a conditioned reflex indicates reactions or quick decision-making.

The physical response time for most people while driving is about the same (average value $0.8 \mathrm{sec}$.), however, significant individual differences relate to the duration of the psychological response and range from 0.4 to $1.2 \mathrm{~s}$. The high value of the reaction time increases the likelihood of an accident, which requires more attention while driving a vehicle [7]. The value of the reaction is not a constant value for a person and many factors can influence its final value. Some of them are individual characteristics of the organism, while others can change towards improvement.

The reaction time of the vehicle driver is one of the most important parameter while ensuring road safety [8]. At the same time, the driver's reaction is considered as a basic professionally important quality in the system of formation of human psychological activity.

Professionally important qualities (PIO) - the qualities of the subject included in the process of activity and ensuring the efficiency of its implementation in terms of productivity, quality of work, and reliability. The importance of PIQ in ensuring the success of the development and implementation of professional activity is determined by the fact that they manifest the main characteristics of the personality structure, which determine the psychological characteristics of the system of activity [8].

Analyzing the actions of a driver when driving a vehicle, there are also five general PIQ of drivers necessary for safe driving: 1) the level of perception of speed and distance, 2) 
assessment of the propensity to take risks, 3) distribution of attention, 4) assessment of emotional stability, 5) complex visual-motor reaction [9].

The main purpose of assessing the PIQ of drivers is identification of conditions contributing to an increase in emergency situations on the roads: inattention, distraction, emotional instability, rapid mental fatigue. Carrying out a researching of the psychophysiological state of a person-driver in the "driver-car-road-environment" system and searching for a correlation between individual parameters of the PVC will further develop recommendations for training on simulators, trainings, practical exercises for both beginners and experienced drivers, which will help reduce road accidents.

\section{Experimental method}

The methodology of studying the psychophysiological state of drivers is based on assessing the speed of reaction to various stimuli and the accuracy of doing tasks. The assessment of psychophysiological characteristics was carried out by analyzing the following characteristics, measured by means of a hardware-software complex for motorists UPDK-MK (company "Neurokom", Russia) [9]:

1) General readiness for work. The test dynamically controls the functional state of the operator. With a low response time and a large number of errors, the subject is in a suboptimal functional state, which affects the increase in the time required for his relaxation.

2) Level of perception of speed and distance (LPSD) - the ability to correctly assess the speed of movement and the distance to objects in a rapidly changing traffic situation;

3) Risk-taking (RT) - tendency to commit unreasonable risky actions while driving;

4) Sharing attention (SA) - the driver's ability to simultaneously control and, if necessary, quickly and accurately perform the most important actions when driving a car, without losing control over other significant aspects of the road situation (manipulating controls, assessing the road situation, communicating with passengers, etc.);

5) Emotional stability (ES) - the driver's ability to drive adequately in the presence of interference and negative emotional factors;

6) Complex visual-motor reaction (CVR-M) - the ability to accurately and promptly respond to changes in the traffic situation (to traffic signals, road signs, maneuvers of other road users, etc.).

A participant in the experiment is in a sitting position at the computer during the test. One of the prerequisites was the creation of a friendly environment aimed at obtaining objective information about his individual psychological characteristics of responding to various signals.

The studies were carried out by 75 people, aged 19 to 30 years. The average age of the subjects was 24 years. Men accounted for $67 \%$ of the total number of subjects, women $33 \%$. The participants in the experiment were divided into three groups (Table 1). Group I candidates (with no driving experience); Group II - non-professional drivers with a driving experience of up to 4 years; Group III - non-professional drivers with more than 4 years of work experience. During the experiment, each participant was asked to pass 6 tests sequentially.

Before the beginning of the testing, the participant of the experiment registered and received an instruction to responsible passing the test, studied the instructions, and proceeded to perform the preliminary test, according to the results of which the subject either continued or completed testing. 
Participants in the experiment

\begin{tabular}{cccc}
\hline Groups & Group size, people & Men, people & Women, people \\
\hline I & 25 & 17 & 8 \\
\hline II & 25 & 16 & 9 \\
\hline III & 25 & 17 & 8 \\
\hline Total & 75 & 50 & 25 \\
\hline
\end{tabular}

The target of this experiment is to determine the results of testing the values of psychophysiological characteristics in the form of marked level. Based on the methods, according to the results of passing the test, a grade of levels is conditionally assigned: D1 the results of all 5 tests within the "norm"; D2 (D3) - "below the norm", ie the results of one (two) tests are outside the "norm"; and D4 - the results of more than three tests are outside the "norm".

\section{Results of the research}

The percentage distribution of participants in the experiment was assessed according to four types of tolerance in each Group, when passing a set of tests. The obtained assessments of the psychophysiological state showed the following results depending on the driving experience of the subjects (Figure 1). Participants in the experiment without driving experience (candidates, Group I) had only $8 \%$ of the results corresponding to the D1 level; the same group had the lowest marks and received the most D4. Group II showed the highest result D1 (28\%). Group II showed the greatest composure, responsibility, and desire to demonstrate high results D1. Group III had only $16 \%$ D1 level. Perhaps due to the fact that as the subjects gain individual experience, there is a certain decrease in self-control due to excessive confidence and neglect of the accuracy of the tasks. The best results of the "normal" state were obtained by the participants of the experiment in all groups when passing Tests 2 and 5 ("Assessment of the risk-taking" and "Complex visual-motor reaction") (Figure 2).

The results obtained were subjected to statistical processing. The analysis was carried out using the Pearson's correlation coefficient. Statistical analysis of the results of passing the tests by the participants in the experiment revealed a correlation dependence of some psychophysiological states. The average level of dependence of risk propensity on driving experience (Pearson's correlation coefficient $r=0.55$ ) and an inverse relationship between the assessment of "Sharing attention" and "Complex visual-motor reaction" $(r=-0.62)$ were revealed. A complex dependence of the assessment of "Complex visual-motor reaction" and "Emotional stability" ( $r=0.75$ ) was revealed. The percentage distribution of the participants in the experiment is shown in table 2 with vulnerable (below normal) psychophysiological states. "Level of perception of speed and distance" and Test-4 "Assessment of the risk-taking" in the presence of driving experience (Groups II and III).

The assessment of emotional stability can be in some area of intertest (Test 4). Emotionally unbalanced drivers are much more likely to violate traffic rules and participants in road accidents.

The emotional state is of great importance in the activities of the driver of the vehicle and in many cases determines the correctness and accuracy of his actions. 


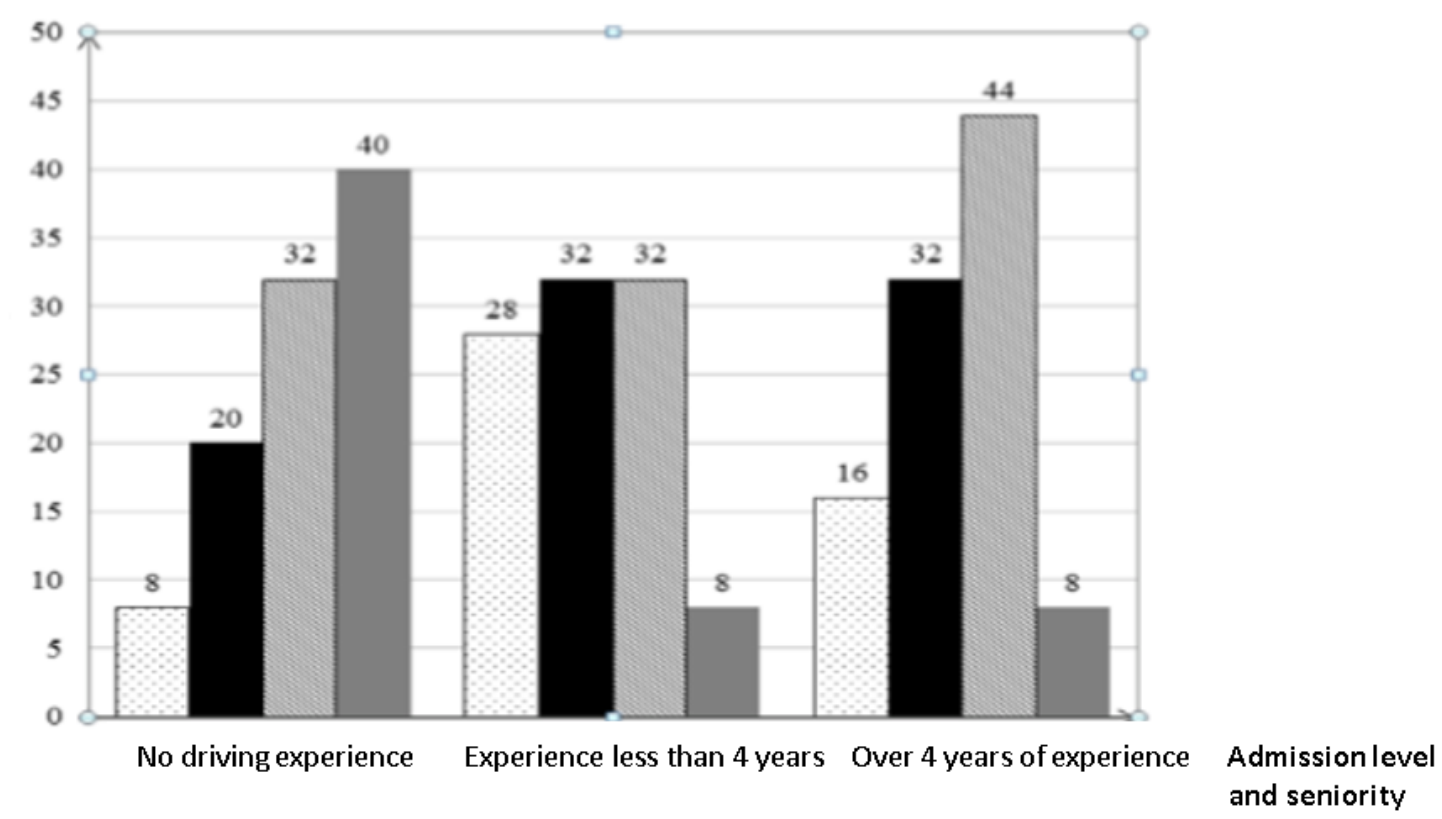

口 Clearance level 1 - Clearance level 2 a' Clearance level $3=$ Clearance level 4

Figure 1. Results of passing tests by experiment participants by type of admission, \%.

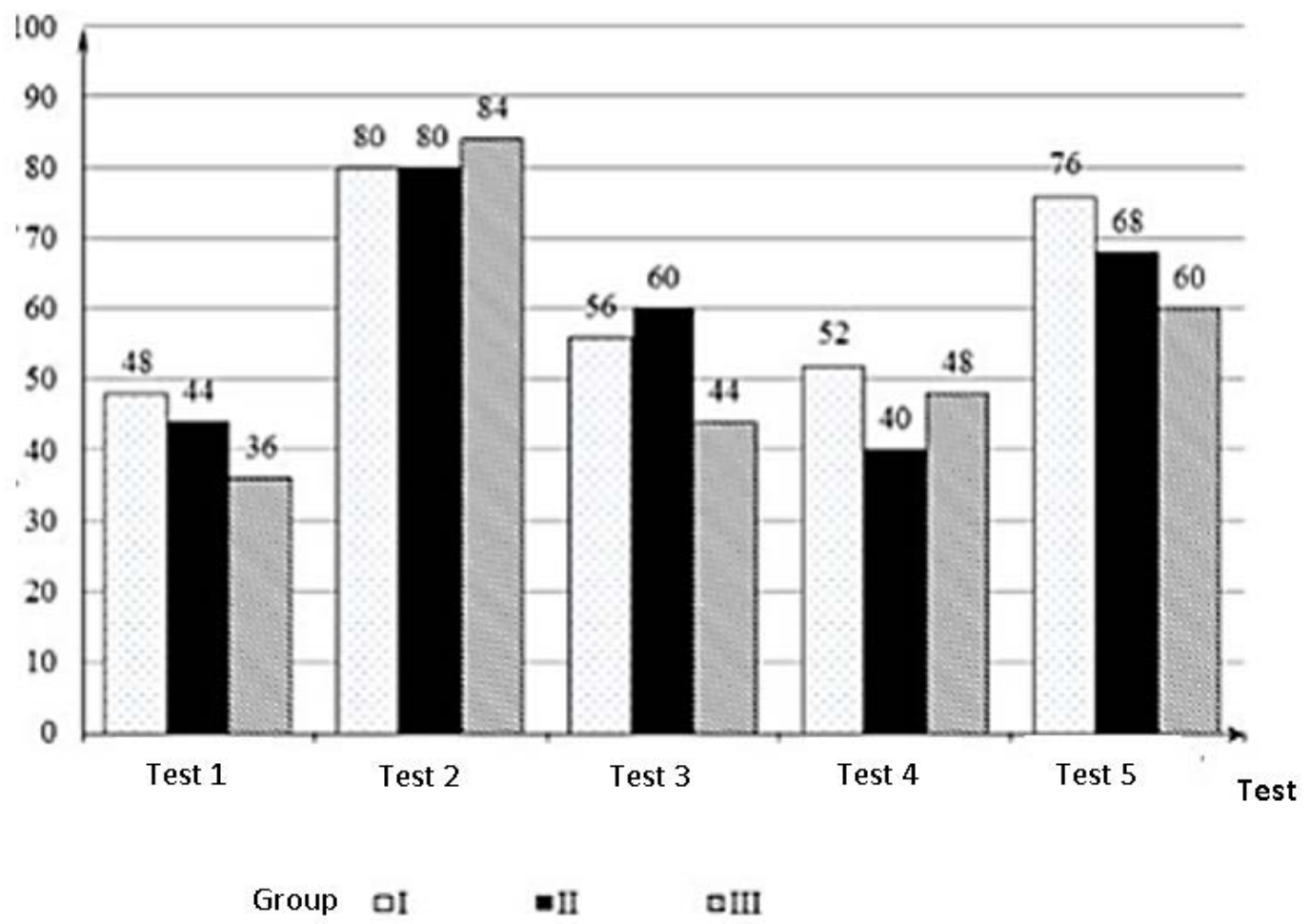

Figure 2. Results of assessments "norm" by three groups of participants in the experiment.

The vehicle driver may have negative emotions associated while driving a vehicle, in addition to the experiences inherent in each person. The reasons for these emotions can produce dangerous situations on the roads, driving in poor visibility conditions, life and health responsibility for the passengers, the unsatisfactory condition of the road surface, poor meteorological conditions (ice, snow, blizzard, and rain), the need for sharp braking and a sudden change in the direction of movement from created traffic situation. 
Table 2

\section{Percentage distribution of experimental participants with vulnerable (below normal)} psychophysiological states

\begin{tabular}{cccccc}
\hline Groups & Test 1 & Test 2 & Test 3 & Test 4 & Test 5 \\
\hline I & 52 & 20 & 44 & 48 & 24 \\
\hline II & 56 & 20 & 40 & 60 & 32 \\
\hline III & 64 & 16 & 56 & 52 & 40
\end{tabular}

A high percentage of "not normal" grade was also established in all groups when assessing the distribution of attention (Test 3) (Figure 3).

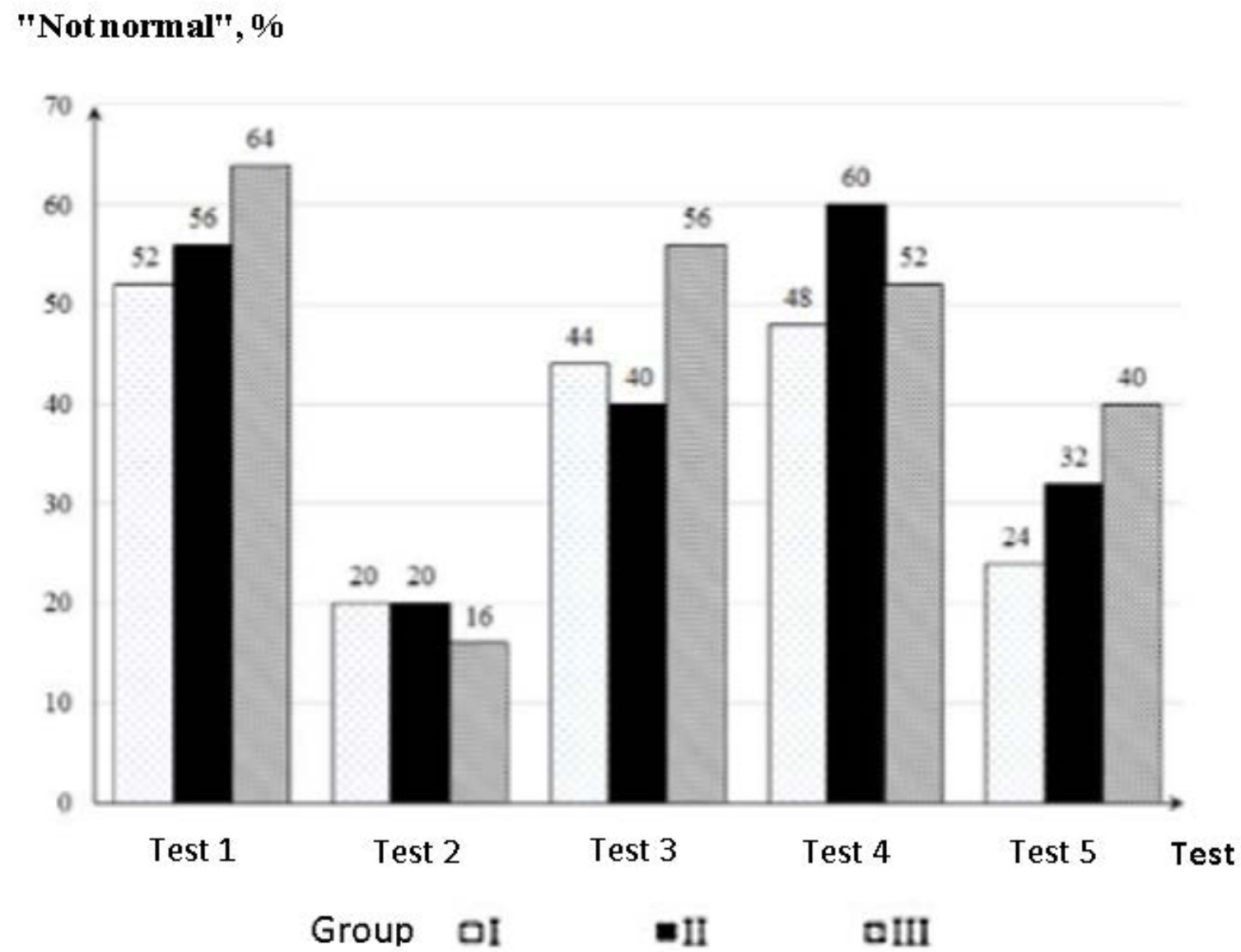

Figure 3. The results of assessing the psychophysiological state "not normal".

The main factor of vehicle driver emotional stress is the necessity of a constant assessment of the continuously changing road situation and in making decisions under conditions of lack of time [10].

The results of the test "Emotional stability" at different stages of the driving experience in Figure 4.

The graph shows that in mixed groups without taking into account the gender difference of the participants in the experiment, Groups I and III are the most emotionally stable. The participants in the experiment who do not have driving experience in Group I (not familiar with the experience of making emergency decisions in an emergency on the road) and drivers with experience in Group III are more emotionally "cold-blooded".

Group II is one of the interesting groups of drivers. Drivers of this group have driving work experience up to 4 years. Gender differences are taking into account. 


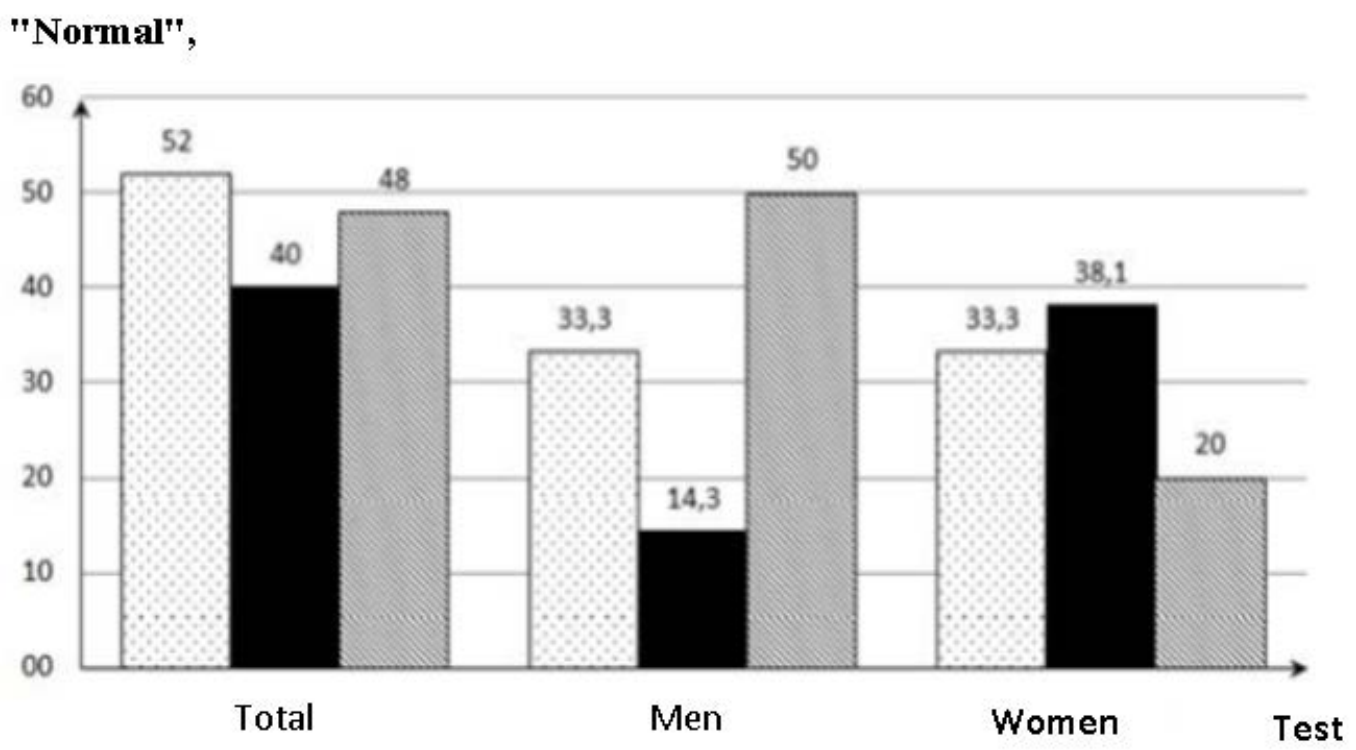

Group aI $\quad$ aII

Figure 4. Assessment of emotional stability.

The graph of assessing emotional stability shows decreasing of emotional stability in any group. It becomes inadequately low for men (they are more relaxed), and then it rises again to the level optimal for this activity (Group III of drivers). Women are more focused and have a high level of emotional stability in Group II, and in Group III they have a lower assessment of emotional stability (fear appears).

The results were statistically processed. The analysis was carried out using the Pearson's correlation coefficient. Statistical analysis of the test results by the participants in the experiment revealed a correlation dependence of some psychophysiological states.

As a result, a strong inversely proportional correlation was revealed between the parameters of psychophysiological characteristics: the average response time of the CVR-M and the indicator of the number of errors without El interference $(r=-0.70)$. Based on this, we can conclude that the less time a driver spends when making a decision while driving, the more likely it is to make mistakes at the decision-making stage and when performing control actions in non-standard situations and in conditions of distraction.

A detailed analysis of the psychophysiological characteristics of drivers shows the average correlation dependence between the distribution of attention and emotional stability $(r=0.5)$, as well as when assessing the LPSD, the number of exact hits has an average correlation dependence on the arithmetic mean of the ES response time $(r=0.5)$. Which means: the higher the emotional stability, the more accurately the vehicle driver is able to assess the speed and distance while driving.

The correlation coefficient of indicators of emotional stability and complex motor response is given in Table 3.

\section{Conclusion}

The analysis of statistical data on the results of assessing the level of the psychophysiological state of a person and data processing in order to determine the relationship of the mutual influence of various parameters of the psychophysiological state with each other. Thus, a strong inversely proportional correlation was found between the parameters of CVR-M and EI $(r=-0.70)$. 
Table 3

The correlation coefficient of indicators of emotional stability and complex motor response is given in the table

\begin{tabular}{|c|c|c|c|c|}
\hline EI CVR-M & $\begin{array}{l}\text { Average } \\
\text { response time } \\
\text { per Task } 1\end{array}$ & Selection time & $\begin{array}{l}\text { Average response } \\
\text { time per Task } 2\end{array}$ & $\begin{array}{l}\text { Difference in } \\
\text { arithmetic mean } \\
\text { response times }\end{array}$ \\
\hline $\begin{array}{l}\text { Number of errors } \\
\text { without interference }\end{array}$ & -0.40 & -0.55 & -0.70 & -0.56 \\
\hline $\begin{array}{l}\text { Arithmetic mean } \\
\text { response time without } \\
\text { interference }\end{array}$ & 0.42 & -0.02 & 0.26 & -0.03 \\
\hline Number of hindrances & 0.42 & -0.04 & 0.25 & -0.04 \\
\hline $\begin{array}{l}\text { Arithmetic mean } \\
\text { response time with } \\
\text { interference }\end{array}$ & 0.36 & -0.10 & 0.16 & -0.10 \\
\hline
\end{tabular}

The presence of a correlation dependence means that when training one type of psychophysiological qualities, a person unwittingly affects other correlation dependent psychophysiological characteristics. Research has also revealed that at different stages of the driving experience, you need to train different characteristics of the PIQ.

These conclusions will make it possible to take into account the dependence of the parameters of the PIQ and will become the basis for the development of practical methods of training drivers' skills in the future and will make it possible to develop recommendations: 1) to create simulators for both technical means and mobile applications; 2) to conduct practical training in driving schools when teaching driving skills; 3) to develop trainings for the acquisition and consolidation of specific skills PIQ driver.

Project: 20.80009.8007.26.

\section{References}

1. Asipovich V.S., Yakovenko R.Y., Scherbina N.V., Yashin K.D. Stress advanced research. In: Int. J. Adv. Res. 2017. Vol. 5 No 5. pp. 2124-2131.

2. Asipovich V.S., Shcherbina N.V., et al. The algorithm, the software and the methodology of stress tolerance assessment. In: Journal of Engineering Science. - 2019. - Vol. 27 No. 4. - pp. 103 - 110.

3. Report on Best Practices in Road Safety Prevention. Moscow, 2018 - 32 p.

4. Vainshtein L.A. Psychology of labor safety: a tutorial [add. Ministry of Defense of the Republic of Belarus] Vainshtein L. A., Yashin K. D. - Minsk: BSUIR, 2019. -254 p.

5. Shupeiko I.G. Ergonomic design of systems "man - machine". I. G. Shupeiko. - Minsk: BSUIR, 2017 .-- 80 p.: ill.

6. Gurevich K.M., Borisova E.M. Psychological diagnostics. Textbook, publishing house URAO, 1997.

7. Pesoshin A.A., Rozhenntsov V.V. Method for assessing the reaction of the driver of a vehicle. In: Bulletin of the Chuvash University. 2012. No. 3

8. Ermakov F.Kh. Technical features of the investigation and establishment of the causes of an accident. F.H. Ermakov, Kazan, 2007.

9. User Guide UPDK-MK [Electronic resource] / JSC "NEUROCOM", Moscow, 2017. - Access mode: http://www.neurocom.ru/ru2/auto/updk_mk_auto_testy.html

10. Morkovkina E.A. Research of professionally important qualities of vehicle drivers. In: Young scientist. 2009. No3. S. $143-151$ 